\title{
Production and carbon reserve dynamics of the seagrass Thalassia testudinum in Corpus Christi Bay, Texas, USA
}

\author{
Kun-Seop Lee, Kenneth H. Dunton* \\ University of Texas at Austin, Marine Science Institute, 750 Channelview Drive, Port Aransas, Texas 78373, USA
}

\begin{abstract}
The seasonal production dynamics of Thalassia testudinum in Corpus Christi Bay, Texas (USA) were evaluated through measurements of biomass, leaf growth and carbohydrate carbon content from December 1993 to March 1995. Shoot density and biomass changed significantly with season; values ranged from 321 shoots $\mathrm{m}^{-2}$ ( $454 \mathrm{~g} \mathrm{dry} \mathrm{wt} \mathrm{m}^{-2}$ ) in March to 531 shoots $\mathrm{m}^{-2}\left(885 \mathrm{~g} \mathrm{dry} \mathrm{wt} \mathrm{m}^{-2}\right)$ in September Biomass of individual plant parts was significantly different over the sampling period; rhizome tissues tended to have the highest biomass while root tissues had the lowest. However, leaf biomass was higher than that of rhizome tissues during summer. Leaf productivities showed significant seasonal variation that was strongly correlated with temperature, ranging from $0.07 \mathrm{~g} \mathrm{dry} \mathrm{wt} \mathrm{m}^{-2} \mathrm{~d}^{-1}$ in

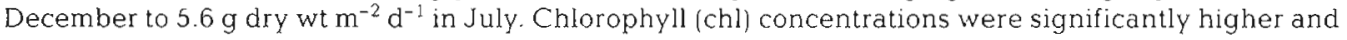
chl $a: b$ ratios lowest during the spring/summer period of maximum photosynthetic production and growth than during winter. Non-structural carbohydrate carbon content was highest in rhizome tissues (111 to $203 \mathrm{mg} \mathrm{C} \mathrm{g}^{-1}$ dry wt) and lowest in leaf tissues (46 to $70 \mathrm{mg} \mathrm{C} \mathrm{g}^{-1}$ dry wt), which is consistent with the rhizome's role as a carbon storage tissue. Rhizome carbohydrate carbon content increased rapidly during June and July, which coincided with high water temperatures, underwater irradiance and blade chl concentrations. During winter and early spring, rhizome carbohydrate carbon content dropped nearly $50 \%$, suggesting that these reserves were mobilized for tissue maintenance and new growth in early spring. Estimated annual blade production of $T$ testudinum in Corpus Christi Bay over the period of this study was $792 \mathrm{~g}$ dry $w \mathrm{t} \mathrm{m}^{-2} \mathrm{yr}^{-1}$, equivalent to $253 \mathrm{~g} \mathrm{C} \mathrm{m}^{-2} \mathrm{yr}^{-1}$ Overall, annual productivity appears to be primarily regulated by temperature and secondarily by irradiance, as reflected in the timing and magnitude of the strong seasonal variations in leaf productivity, total chl content, chl $a: b$ ratios and rhizome carbohydrate carbon content in $T$ testudinum.
\end{abstract}

KEY WORDS: Seagrass - Biomass P Production · Non-structural carbohydrates - Chlorophyll - Thalassia testudinum $\cdot$ Carbon dynamics

\section{INTRODUCTION}

Seagrass meadows are among the most productive of plant communities (McRoy \& McMillan 1977), providing habitat and food for a wide variety of flora and fauna (Heck \& Westone 1977, Orth et al. 1984, Summerson \& Peterson 1984, Huh \& Kitting 1985). Although few herbivores consume seagrass directly (Ogden 1980, Mann 1988), a substantial fraction of seagrass carbon enters coastal and estuarine food webs through

\footnotetext{
- Addressee for correspondence.

E-mail:dunton@utmsi.zo.utexas.edu
}

microbial transformation of litter and particulate detritus (Kenworthy \& Thayer 1984, Mann 1988, Chin-Leo \& Benner 1991, Peduzzi \& Herndl 1991, Koepfler et al. 1993, Opsahl \& Benner 1993).

Accurate assessment of total seagrass production is difficult since a substantial fraction of plant biomass is below-ground. However, net above-ground production of seagrasses having strap-like leaves can be easily estimated using leaf marking techniques (Zieman 1974, Vermaat et al. 1987). Leaf production shows clear seasonal trends with rates increasing in spring and summer and decreasing in fall and winter (Vermaat et al. 1987, Dunton 1994). In spring, when water 
temperature and day length increase, leaf production rates increase primarily due to the creation of new leaves which are thought to originate mainly from stored carbon in the rhizomes, while higher leaf production rate in summer is due to growth of existing leaves (Dawes \& Lawrence 1980, Dawes \& Guiry 1992, Tussenbroek 1995).

Seasonal growth of seagrasses is probably regulated by insolation and temperature or an interaction of both (Wetzel \& Penhale 1983, Dunton 1994). Some researchers have considered temperature as the primary factor controlling seasonal growth (Setchell 1929, Tutin 1942, Phillips et al. 1983). However, Sand-Jensen \& Borum (1983) stated that water temperature did not correlate with seasonal trends in leaf productivities. In addition, endogenous circannual rhythms of leaf elongation have been suggested for Posidonia oceanica, Thalassia testudinum and Halodule wrightii (Ott 1979, Dunton 1994, Czerny \& Dunton 1995).

Production dynamics of above-ground tissues of seagrasses are generally well documented, but the metabolic features and functional role of below-ground tissues in whole plant production dynamics are less well known (Kraemer \& Alberte 1993). The below-ground portion of Thalassia testudinum can account for over $50 \%$ of the total biomass (Powell et al. 1989, Fourqurean \& Zieman 1991), and is supported by photosynthetically derived carbon and oxygen (Smith et al. 1984, Caffrey \& Kemp 1991, Ralph et al. 1992). Seagrass rhizomes serve as carbohydrate storage tissues, in the form of soluble carbohydrate carbon, that support growth and maintenance of other plant parts during periods of low photosynthetic production (Dawes \& Lawrence 1979, 1980, Durako \& Moffler 1985, Pirc 1985, Dawes \& Guiry 1992). Therefore, production, metabolism and stored carbon content of belowground tissues must be considered when deriving estimates of whole plant carbon balance (Fourqurean \& Zieman 1991, Kraemer \& Alberte 1993).

Pirc $(1985,1989)$ found that seasonal changes of rhizome carbohydrate concentrations in Posidonia oceanica and Cymodocea nodosa were characterized by seasonal maxima in summer and fall, with winter growth and maintenance supported by the mobilization of starch from the rhizome. In Thalassia testudinum, increases in rhizome carbohydrates in summer have been attributed to the production and storage of starch, while winter and spring decreases were linked to the utilization of these stored carbohydrates for growth and maintenance (Dawes \& Lawrence 1979, 1980, Durako \& Moffler 1985). Although carbohydrate carbon in belowground tissues plays an important role in growth and survival of seagrass, little research has been conducted on carbohydrate carbon partitioning into different plant parts, particularly on a seasonal basis.
Since most of the work on Thalassia testudinum in the Gulf of Mexico has been conducted in Florida (USA), this study provides valuable comparative data on the biology of this species in Texas (USA). Our emphasis is focused on seasonal changes in plant biomass, carbohydrate carbon content, leaf chlorophyll, and leaf productivity in relation to coincident measurements of temperature and continuous measurements of underwater photosynthetically active radiation (PAR). We also examined seasonal changes in carbohydrate carbon partitioning into different plant parts encompassing leaves, rhizomes, short shoots and roots.

\section{MATERIALS AND METHODS}

Study site. The study site (East Flats) is located on the eastern side of Corpus Christi Bay $\left(27^{\circ} 49^{\prime} \mathrm{N}\right.$, $97^{\circ} 7^{\prime} \mathrm{W}$ ) and has been the focus of several recent investigations on south Texas seagrasses (Dunton 1990, 1994, Czerny \& Dunton 1995). Thalassia testudinum. Halodule wrightii and Syringodium filiforme are the dominant seagrass species in this area. This study was conducted on a monotypic meadow of $T$. testudinum at an average water depth of $1.2 \mathrm{~m}$. Sediments are composed of $78 \%$ sand and shell, $8 \%$ silt, and $14 \%$ clay and water temperatures generally range from $34^{\circ} \mathrm{C}$ in July and August to $13^{\circ} \mathrm{C}$ in January, with salinities varying between 27 and 32\%o (Dunton 1990 19941.

Production and biomass measurements. Monthly measurements of shoot density, biomass, leaf chlorophyll content, carbohydrate carbon content and leaf production rates were made from December 1993 to March 1995. Four replicate biomass samples were collected with a $9 \mathrm{~cm}$ diameter coring device driven 15 to $20 \mathrm{~cm}$ into the sediments. Samples were thoroughly cleaned of epiphytes and sediments, separated into leaf (blade and sheath), short shoot (vertical rhizome), rhizome and root tissues, and dried at $60^{\circ} \mathrm{C}$ to a constant weight. Shoot density was estimated by counting the number of shoots inside a randomly thrown quadrat $\left(0.05 \mathrm{~m}^{2} ; \mathrm{n}=4\right.$ to 8$)$.

Leaf production rates were obtained using the blade marking technique (Zieman 1974, Kentula \& McIntire 1986). Five sampling areas were marked with PVC poles in a monotypic Thalassia testudinum bed. Fifteen to 20 randomly chosen shoots around these poles were marked just above the bundle sheath with a hypodermic needle and collected after 12 to $16 \mathrm{~d}$. Leaf production rate per shoot was determined by dividing the dry weight of new leaf tissue produced by the number of days since marking. Areal leaf production rates were obtained by multiplying shoot leaf production rates by the shoot density. Leaf production rate per shoot was 
correlated with in situ water temperature and underwater irradiance measured during periods of leaf marking

Chemical analyses. For determination of blade chlorophyll (chl) content, 6 replicate samples from each sampling date were collected and cleaned of epiphytes by gentle scraping in the laboratory. Preweighed leaf tissue was ground in $90 \%$ cold acetone buffered with $0.05 \% \mathrm{MgCO}_{3}$ using chilled pestles and mortars with washed sea sand. The extract was made up to a known volume, centrifuged, and absorbances measured at 750,664 and $647 \mathrm{~nm}$ on a Shimadzu UV $160 \mathrm{U}$ spectrophotometer. $\mathrm{Chl} a$ and $b$ contents were determined using the equations of Jeffrey \& Humphrey (1975) for $90 \%$ acetone extractions.

Dried plant material from biomass samples was used to determine total non-structural carbohydrate (starch + soluble sugars) carbon content in different plant parts. Total non-structural carbohydrates from leaf, horizontal rhizome, vertical rhizome and root were determined using the MBTH (3-methyl-2-benzothiazolinone hydrazone hydrochloride) analysis (Parsons et al. 1984, Pakulski \& Benner 1992). Ground plant samples were hydrolyzed with dilute $\mathrm{HCl}$. The hydrolyzed samples were neutralized with $\mathrm{NaOH}$ solution, followed by reduction to alditols with $\mathrm{KBH}_{4}$. The alditols were oxidized with periodic acid solution to form $2 \mathrm{~mol}$ of formaldehyde per mol of monosaccharide. The aldehyde content was determined spectrophotometrically with MBTH. Absorbances were compared with a glucose standard and converted to equivalent carbon values ( $\mathrm{mg} \mathrm{C}^{-1}$ dry $w \mathrm{t}$ ).

Four replicate surface water samples for determination of water column dissolved inorganic nitrogen (DIN, $\mathrm{NO}_{3}{ }^{-}+\mathrm{NO}_{2}{ }^{-}$) were collected every month. DIN was determined colorimetrically according to Parsons et al. (1984).

Photon flux measurement. Photosynthetically active radiation (PAR, 400 to $700 \mathrm{~nm}$ ) was collected continuously using an LI-193SA spherical quantum sensor that recorded PAR at canopy level in conjunction with an LI-1000 datalogger (LI-COR Inc., Lincoln, NB, USA) enclosed in an underwater housing. The underwater quantum sensor was cleaned regularly to minimize fouling. Photon flux density (PFD, umol $\mathrm{m}^{-2} \mathrm{~s}^{-1}$ ) was measured at 1 min intervals and integrated hourly. Daily PFD ( $\mathrm{mol} \mathrm{m}^{-2} \mathrm{~d}^{-1}$ ) was calculated as the summation of quantum flux over each 24 h period.

Statistics. All values are reported as means $\pm 1 \mathrm{SE}$. Statistical analyses were performed on a microcomputer using a general linear model procedure (SAS Institute 1989). Significant differences in underwater irradiance, density, chl content, chl $a: b$ ratios and leaf productivity among sampling times were tested using a 1-way ANOVA. A 2-way ANOVA was used to test significant differences in biomass and carbohydrate carbon content among sampling times and plant parts. When a significant difference among variables was observed, the means were analyzed by a Tukey multiple comparison test to determine where the significant differences occurred among variables.

\section{RESULTS}

\section{Physical and chemical parameters}

Underwater PFD, which was collected on a continuous basis from October 1993 to January 1995, exhibited a high degree of fluctuation (Fig. 1A). Average daily PFD ranged from $9.6 \mathrm{~mol} \mathrm{~m}^{-2} \mathrm{~d}^{-1}$ in April to $21.7 \mathrm{~mol}$ $\mathrm{m}^{-2} \mathrm{~d}^{-1}$ in July. Daily maximal PFD ranged from 50 to $1450 \mu \mathrm{mol} \mathrm{m} \mathrm{m}^{-2} \mathrm{~s}^{-1}$ and did not show a seasonal trend. The annual quantum flux at the seagrass canopy was $5382 \mathrm{~mol} \mathrm{~m} \mathrm{mr}^{-1}$, which corresponded to $47 \%$ of surface irradiance (SI). In contrast, water temperature showed a strong seasonal trend ranging from $13^{\circ} \mathrm{C}$ in January to $30^{\circ} \mathrm{C}$ in August (Fig. 1B). Water column DIN concentrations, which were almost always less than $1 \mu \mathrm{M}$ during the study period, did not show any distinct seasonal trend (Fig. 2).

\section{Density, biomass and leaf production}

Shoot (sht) density and total biomass showed significant seasonal variations $(p<0.001$ and $p=0.019$ respectively); values ranged from 321 shts $\mathrm{m}^{-2}$ (454 g

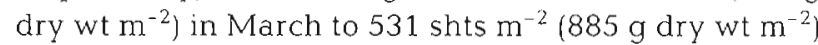
in September (Fig. 3A), Biomass of individual plant parts was significantly different ( $p<0.001$; Fig. 3B) Leaf and root biomass also showed significant seasonal variation ( $p<0.001$ and $p=0.0026$, respectively), but rhizomes and short shoots did not $(p=0.777$ and $p=$ 0.418 , respectively). Leaf biomass was highest in September (355 $\mathrm{g}$ dry wt $\mathrm{m}^{-2}$ ) and lowest in early April (81 $\mathrm{g}$ dry wt $\mathrm{m}^{-2}$ ), while root biomass was highest in September (103 $\left.\mathrm{g} \mathrm{dry} \mathrm{wt} \mathrm{m}^{-2}\right)$ and lowest in late February (43 $\mathrm{g}$ dry $w \mathrm{w} \mathrm{m}^{-2}$ ). Seasonal changes in total biomass were closely correlated with variations in leaf biomass which showed higher annual variability as compared to that of other plant parts (Fig. 3A, B).

On an annual basis, rhizome tissues accounted for about $40 \%$ of total biomass, while root tissues accounted for about $12 \%$ of total biomass. Biomass partitioning into leaf tissues significantly changed with season ( $p<0.001)$; leaf tissues accounted for $17 \%$ of total biomass in April and $41 \%$ in. July. Biomass partitioning into rhizome tissues did not change with season $(p=0.08)$ 


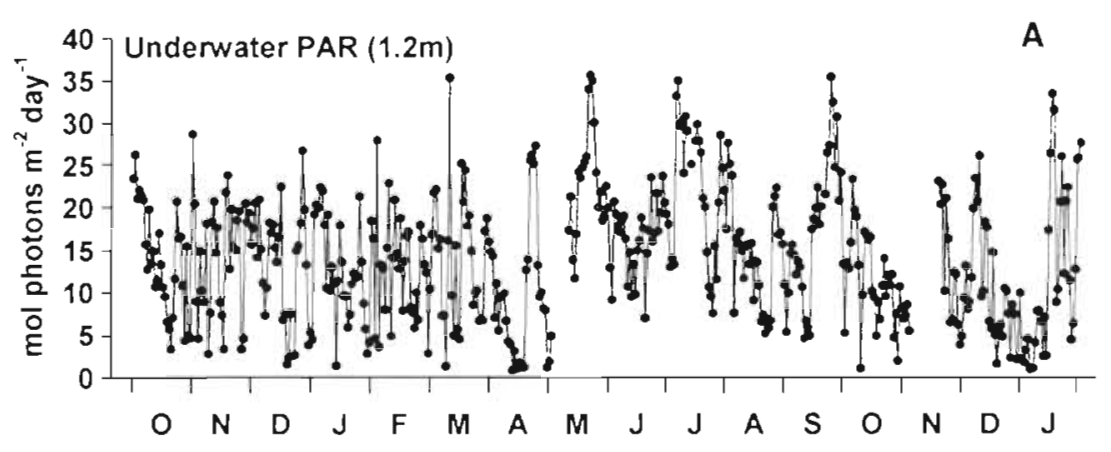

B

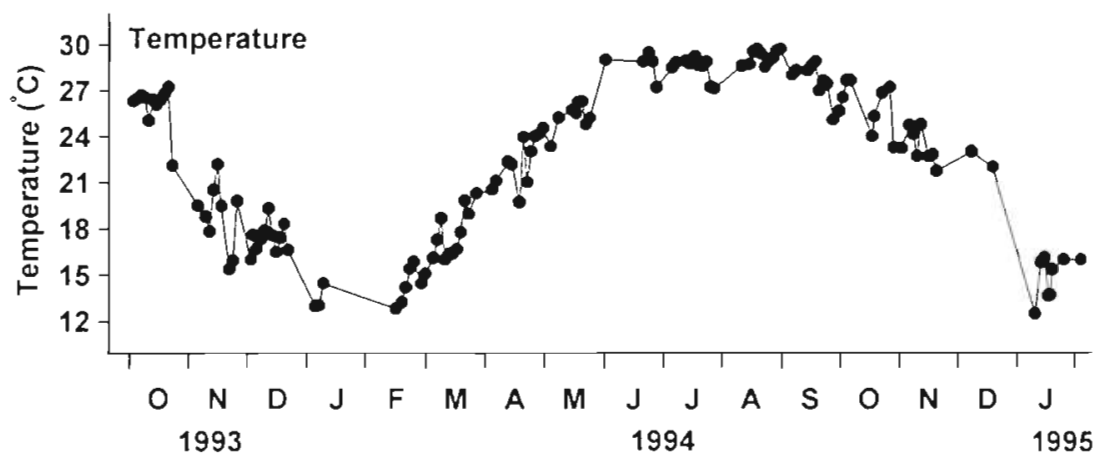

Fig. 1 (A) Daily irradiance recorded at canopy level and (B) water temperature in a Thalassia testudinum bed in Corpus Christi Bay (Texas, USA) from October 1993 to January 1995

Shoot production, as reflected by leaf growth (mg dry wt sht ${ }^{-1} \mathrm{~d}^{-1}$ ), and areal leaf production ( $\mathrm{g}$ dry wt $\mathrm{m}^{-2} \mathrm{~d}^{-1}$ ) changed significantly with sampling time ( $\mathrm{p}<$ 0.001 ), increasing during spring and summer, decreasing during fall, and approaching zero between December and February (Fig. 4). Leaf production was highest in July (12 mg dry wt sht $\mathrm{m}^{-1} \mathrm{~d}^{-1}$ or $5.6 \mathrm{~g}$ dry wt $\mathrm{m}^{-2} \mathrm{~d}^{-1}$ ) and lowest in December $\left(0.2 \mathrm{mg}\right.$ dry wt sht $\mathrm{t}^{-1} \mathrm{~d}^{-1}$ or $0.07 \mathrm{~g}$ dry wt $\mathrm{m}^{-2} \mathrm{~d}^{-1}$ ), and was closely correlated with water temperature changes throughout the year $\left(r^{2}=\right.$

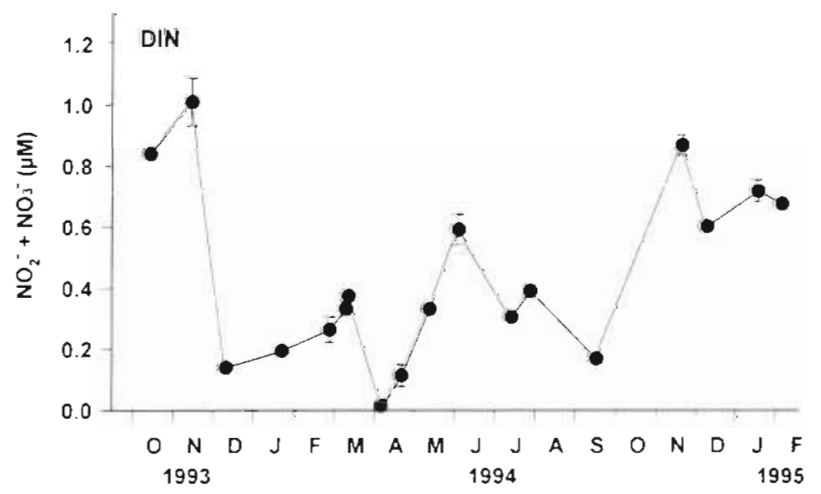

Fig. 2. Water column DIN $\left(\mathrm{NO}_{3}^{-}+\mathrm{NO}_{2}^{-}\right)$concentrations in Corpus Christi Bay trom October 1993 to January 1995. Values are mean $\pm \operatorname{SE}(n=4)$. Where no error bars appear, SE is less than the size of the symbol
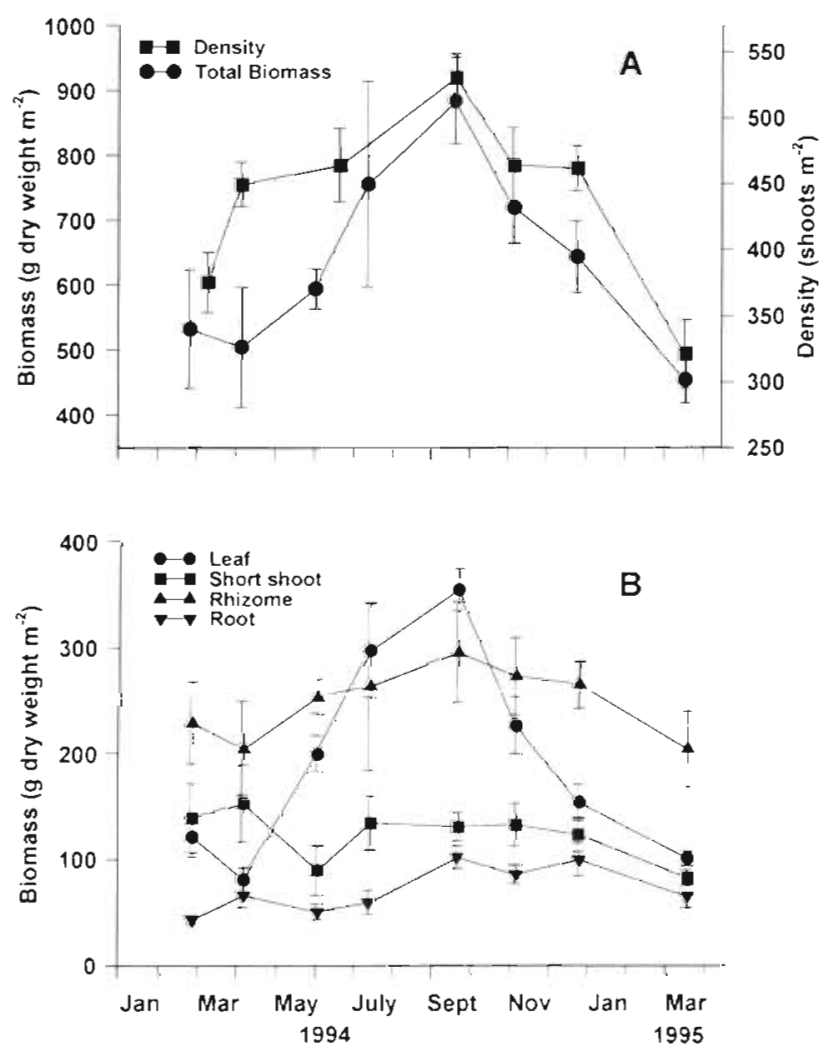

Fig. 3. Thalassia testudinum. Seasonal changes in (A) density and total biomass and $(B)$ blomass of different plant components. Values are mean \pm SE $(n=4$ to 8$)$ 


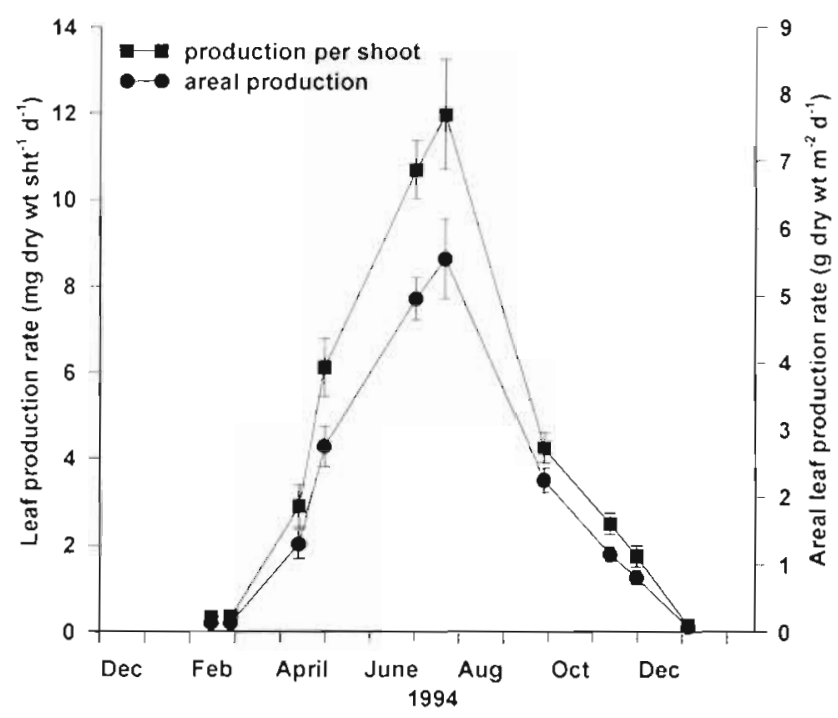

Fig. 4. Thalassia testudinum. Seasonal changes in leaf production rates per shoot and areal leaf production rate from February 1994 to January 1995. Values are mean $\pm \mathrm{SE}(\mathrm{n}=5$ to 16$)$

0.73). Productivity increased rapidly with increasing temperature during spring and summer and decreased rapidly with falling temperatures during fall and winter (Fig. 5A). On an annual basis, there was not a strong correlation between underwater irradiance and leaf productivity $\left(\mathrm{r}^{2}=0.41\right.$; Fig. $\left.5 \mathrm{~B}\right)$.

\section{Chlorophyll}

Total chl content from Thalassia testudinum leaf tissue changed significantly with sampling time ( $\mathrm{p}=$ 0.004 ), ranging from $8.3 \mathrm{mg} \mathrm{chl} \mathrm{g}{ }^{-1}$ dry wt in June to $6.3 \mathrm{mg} \mathrm{chl} \mathrm{g}^{-1}$ dry wt in February (Fig. 6). Chl content increased during spring, remained constant until early winter and decreased later in the winter. Chl $a: b$ ratios also changed significantly with sampling time ( $p<$ 0.001 ), ranging from 2.9 in September to 3.2 in December (Fig. 6). In general, chl a: $b$ ratios varied inversely with respect to total chl content, with highest values of total chl associated with higher proportions of chl $b$ relative to chl a.

\section{Non-structural carbohydrate carbon content}

Total non-structural carbohydrate carbon content (based on $0.1 \mathrm{~N} \mathrm{HCl}$ hydrolysis) was significantly different with sampling date $(\mathrm{p}<0.001)$ and among different plant parts $(\mathrm{p}<0.001)$. Thalassia testudinum had highest carbohydrate carbon content in mid-July and lowest in early June (Fig. 7). On an annual basis, aver-
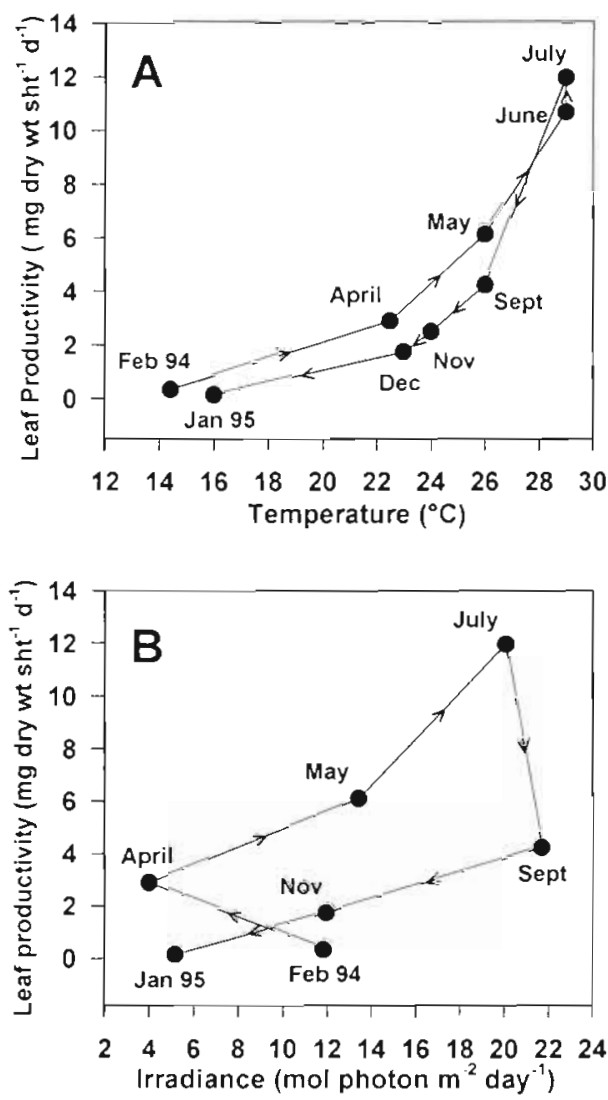

Fig. 5. Thalassia testudinum. Relationships between leaf productivity and (A) water temperature and (B) underwater irradiance from February 1994 to January 1995

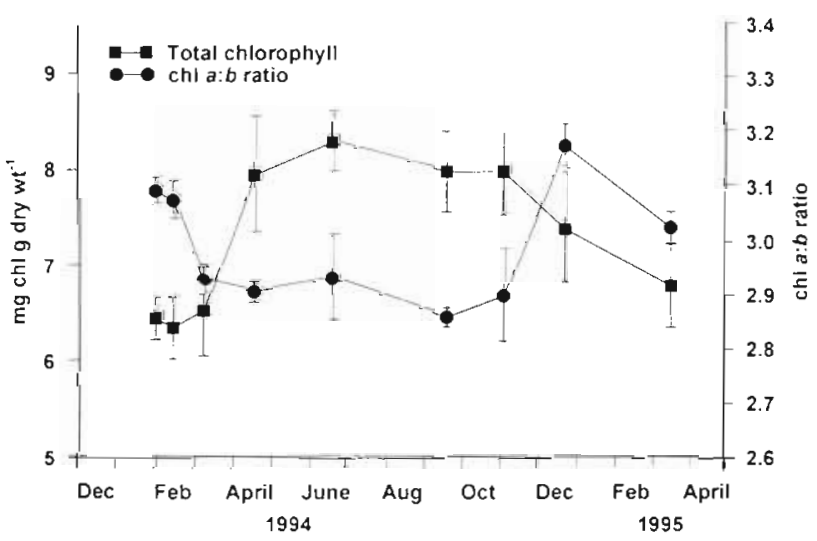

Fig. 6. Thalassia testudinum. Seasonal changes in total chlorophyll concentration and chl $a: b$ ratio in blades of plants collected from January 1994 to March 1995. Values are mean

$$
\pm \operatorname{SE}(n=6)
$$

age carbohydrate carbon content was highest in rhizome tissues (159 $\mathrm{mg} \mathrm{C} \mathrm{g}^{-1}$ dry $w t$ ) and lowest in leaf tissues (59 $\mathrm{mg} \mathrm{C} \mathrm{g}^{-1}$ dry wt). Rhizome and short shoot carbohydrate carbon content increased rapidly during 


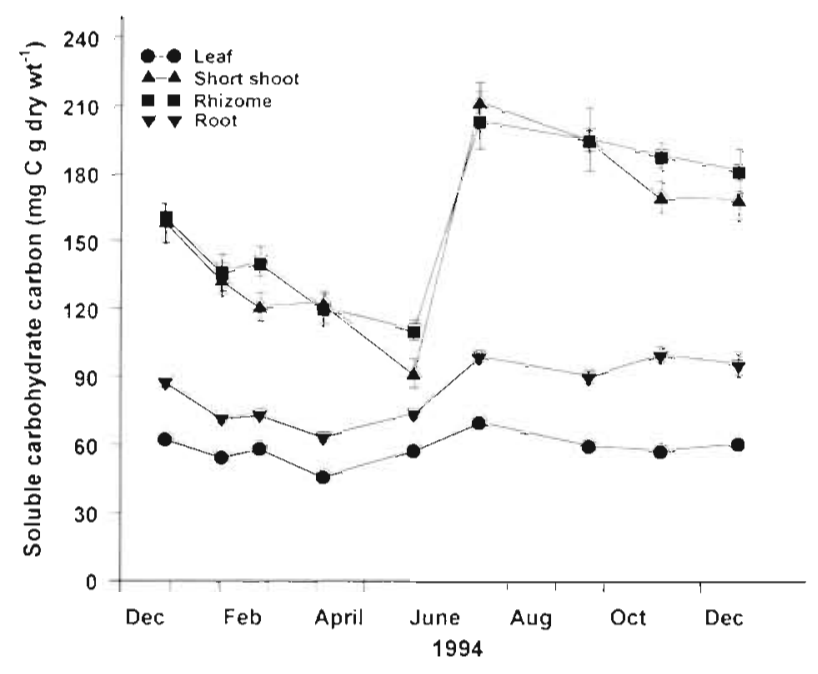

Fig. 7. Thalassia testudinum. Seasonal changes of total nonstructural carbohydrate carbon content in leaf, short shoot, rhizome and root tissues. Values are mean $\pm \mathrm{SE}(n=4$ to 5$)$

June and July, from 110 and 92 to 203 and $212 \mathrm{mg} \mathrm{C}$ $\mathrm{g}^{-1}$ dry wt, respectively, doubling over a 2 mo period. Levels decreased slightly during fall and decreased rapidly during winter and early spring. Total nonstructural carbohydrate carbon content in leaves and roots showed little seasonal variation, with small increases during late spring and early summer, constant values in fall and early winter, and small decreases during late winter and early spring.

Total non-structural carbohydrate carbon estimated on an areal basis ( $\mathrm{g} \mathrm{C} \mathrm{m}^{-2}$ ) also varied significantly with sampling time $(p<0.001)$ and among different plant parts $(\mathrm{p}<0.001)$. Total seagrass carbohydrate carbon was highest in September $\left(115 \mathrm{~g} \mathrm{C} \mathrm{m}^{-2}\right)$ and lowest in April (51 $\mathrm{g} \mathrm{C} \mathrm{m}^{-2}$ ). Non-structural carbohydrate carbon in rhizome ranged from $25 \mathrm{~g} \mathrm{C} \mathrm{m}^{-2}$ in April to $58 \mathrm{~g} \mathrm{C} \mathrm{m}^{-2}$ in September, and accounted for about $50 \%$ of total seagrass non-structural carbohydrate carbon throughout the year. Leaf carbohydrate carbon accounted for $8 \%$ of total seagrass carbohydrate carbon in April and $23 \%$ in June, while short shoot and root carbohydrate carbon accounted for an average of 25 and $8 \%$, respectively, of total seagrass non-structural carbohydrate carbon in the seagrass bed.

\section{DISCUSSION}

\section{Biomass and production}

Thalassia testudinum in Corpus Christi Bay exhibited strong seasonal variations in density, biomass and leaf productivity, which increased during spring and summer and decreased during fall and winter. Similar trends in seagrass standing crop and production have been reported for $T$. testudinum and other species earlier by several authors (Macauley et al. 1988, Dunton 1990, Thom 1990), and were attributed to changes in water temperature and insolation. Temperature has been considered as a major factor controlling seasonal growth (Tutin 1942, Phillips et al. 1983) because of its significant effect on the biochemical process involved in photosynthesis and tissue metabolism (Bulthuis 1987). However, some researchers have reported a poor correlation between water temperature and leaf productivity (SandJensen \& Borum 1983). In this study, there was a strong correlation between leaf productivities and water temperature. If plotted on a log scale, leaf productivity displayed an even stronger correlation with temperature $\left(r^{2}=0.95\right)$, suggesting exponential changes in leaf productivity as a function of temperature. In contrast, with the exception of the late spring and summer periods, no relationship was apparent between leaf productivity and underwater irradiance. For example, leaf productivities increased from 0.4 to $2.9 \mathrm{mg}$ dry wt sht ${ }^{-1} \mathrm{~d}^{-1}$ during early spring (February to April 1994) when underwater irradiance decreased from 12 to $4 \mathrm{~mol} \mathrm{~m}^{-2} \mathrm{~d}^{-1}$ (Fig. 5B). Based on these data, water temperature appears to regulate leaf productivity during fall to early spring, while both water temperature and underwater irradiance play a role during late spring and summer. Since early spring and winter growth appear to be supported by stored reserves in the below-ground tissues, temperature is probably a more important factor controlling seasonal growth than insolation because of its significant role in plant metabolism (Bulthuis 1987). Accordingly, underwater light reduction during the winter and early spring may affect seagrass production less than during summer (Czerny \& Dunton 1995).

No significant correlation $\left(\mathrm{r}^{2}=0.065, \mathrm{p}=0.475\right)$ was found between leaf productivities and ambient DIN. Dunton (1996) reported that pore water ammonium levels in the study site (East Flats) were extremely variable and showed no seasonal trend. Therefore, water column DIN and sediment ammonium probably were not major controlling factors for seasonal growth in this study area.

Leaf production reflected seasonal changes in leaf biomass, increasing during spring and summer and decreasing during fall and winter. On the other hand, rhizome biomass was relatively constant throughout the year. Additionally, although root tissue exhibited significant seasonal variation, it accounts for a small portion of total seagrass biomass and hence does not have a noticeable effect on total biomass. Therefore, seasonal changes in Thalassia testudinum total bio- 
mass occurred as a consequence of variations in leaf biomass. More metabolically active plant tissues, namely the leaf (photosynthetic organ) and root (nutrient absorption site), showed significant seasonal biomass variations, while the rhizome storage tissue did not.

To accurately estimate carbon balance, a better understanding of below-ground tissue dynamics is necessary, since below-ground tissues can constitute a significant portion of total plant biomass. However, few complete annual measurements of the Thalassia testudinum biomass divided into different plant parts have been reported; most research has been concerned with standing crop and conducted only for a short time period. Zieman (1975) reported that $T$. testudinum leaf tissues accounted for 15 to $22 \%$ of total biomass and the remainder was root and rhizome. However, as noted here, the partitioning of biomass to above- and below-ground tissues can show strong seasonal trends. In summer, leaf tissues can account for about $40 \%$ of total biomass, but only 15 to $20 \%$ during winter (rhizome biomass remains fairly constant at $40 \%$ throughout the year). Such distinct seasonal variations in the partitioning of above- and below-ground tissues can be critical in determinations of annual carbon balance in $T$. testudinum.

Seagrass communities contribute significantly to the primary production of shallow coastal ecosystems (Kentula \& McIntire 1986, Roman \& Able 1988, Peduzzi $\&$ Herndl 1991). To estimate the role of seagrasses in the carbon budget of a coastal ecosystem, the annual primary production of seagrasses has been estimated (Roman \& Able 1988, Pergent \& Pergent-Martini 1991 , Gallegos et al. 1993). In this study, an annual blade production of $792 \mathrm{~g}$ dry wt $\mathrm{m}^{-2} \mathrm{yr}^{-1}$ was calculated by adding measurements of leaf productivity for the entire annual period. It must be noted that blade production did not include sheath production. Preliminary elemental analysis indicated that about $32 \%$ of total dry weight was attributed to carbon. Thus, the annual blade production of $792 \mathrm{~g}$ dry wt $\mathrm{m}^{-2} \mathrm{yr}^{-1}$ is equivalent to $253 \mathrm{~g} \mathrm{C} \mathrm{m}^{-2} \mathrm{yr}^{-1}$.

Shoot density of Thalassia testudinum in Corpus Christi Bay was similar to those reported for most other geographical areas (Table 1). Although biomass values for Cancun (Mexico) were similar to values from the present study, total biomass in the present study was much higher than values reported from Egmont Key and Anclote Key, Florida. Compared to low leaf biomass reported in Belize and Puerto Morelos (Mexico), leaf biomass in Corpus Christi Bay was almost 10 -fold higher. Leaf productivities in Corpus Christi Bay were also high in comparison with values from other geographical areas, except for those in Cancun (Table 1). Biomass and leaf productivities appeared to vary as a function of water depth, sediment characteristics and temperature. Local environmental parameters are probably the most important determinators of biomass and productivity in this subtropical species.

Table 1 Thalassia testudinum. Density, biomass and leaf production at various geographical locations

\begin{tabular}{|c|c|c|c|c|c|c|}
\hline $\begin{array}{l}\text { Area } \\
\text { (Depth) }\end{array}$ & $\begin{array}{l}\text { Density } \\
\left(\text { sht } \mathrm{m}^{-2}\right)\end{array}$ & $\begin{array}{c}\text { Biomass } \\
\text { (g dry wt } \mathrm{m}^{-2} \text { ) }\end{array}$ & $\begin{array}{r}\text { Leaf pro } \\
\left(\mathrm{mg} \text { dry wt } \mathrm{sht}^{-1} \mathrm{~d}^{-1}\right)\end{array}$ & $\begin{array}{l}\text { uction } \\
\text { (g dry wt } \mathrm{m}^{-2} \mathrm{~d}^{-1} \text { ) }\end{array}$ & Time & Source \\
\hline \multicolumn{7}{|c|}{ Egmont Key, Florida, USA } \\
\hline$(0.4 \mathrm{~m})$ & $659 \pm 82$ & 217.7 & $17.88 \pm 5.58$ & & June & Dawes \& Tomasko (1988) \\
\hline$(2.5 \mathrm{~m})$ & $1128 \pm 224$ & 107.6 & $7.24 \pm 2.56$ & & June & Dawes \& Tomasko (1988) \\
\hline \multicolumn{7}{|c|}{ Anclote Key, Florida } \\
\hline$(1 \mathrm{~m})$ & $454 \pm 102$ & 73.7 & $3.05 \pm 1.55$ & & July & Dawes \& Tomasko (1988) \\
\hline$(2.5 \mathrm{~m})$ & $285 \pm 109$ & 80.0 & $3.52 \pm 2.49$ & & July & Dawes \& Tomasko (1988) \\
\hline \multicolumn{7}{|l|}{ Belize } \\
\hline$(0.5 \mathrm{~m})$ & $117-404$ & $17.3-49.2^{\text {ॠ }}$ & $1.6-6.1$ & & May-June & Tomasko \& Lapointe (1991) \\
\hline$(2.0 \mathrm{~m})$ & $106-260$ & $22.3-48.6^{a}$ & $1.9-6.1$ & & May-June & Tomasko \& Lapointe (1991) \\
\hline \multicolumn{7}{|l|}{ Honduras } \\
\hline $\begin{array}{l}(0.5 \mathrm{~m}) \\
(2.0 \mathrm{~m})\end{array}$ & $\begin{array}{l}372 \pm 19 \\
324 \pm 4\end{array}$ & & & & $\begin{array}{l}\text { May-June } \\
\text { May-June }\end{array}$ & $\begin{array}{l}\text { Tomasko \& Lapointe (1991) } \\
\text { Tomasko \& Lapointe (1991) }\end{array}$ \\
\hline \multicolumn{7}{|c|}{ Puerto Morelos, Mexico } \\
\hline$(2.5-4.5 \mathrm{~m})$ & $547-661$ & $24.5-57.0^{\mathrm{a}}$ & & $0.88-1.46$ & Annual mean & Tussenbroek (1995) \\
\hline Cancun, Mexico & $480-1222$ & $482-1160$ & & $6.38 \pm 2.3$ & & Gallegos et al. (1993) \\
\hline Florida Bay & & & & $0.05-3.42$ & Summer & Zieman et al. (1989) \\
\hline Playa Habana, Cub & & & & $1.6-18.1$ & & Buesa $(1974)$ \\
\hline U.S. Virgin Islands & $80-200$ & & $0.4-1.2$ & $0.03-0.3$ & April-Nov & Williams $(1988\}$ \\
\hline $\begin{array}{l}\text { Corpus Christi Bay, } \\
(1.2 \mathrm{~m})\end{array}$ & $\begin{array}{l}\text { Texas } \\
321-531\end{array}$ & $454-885$ & $0.15-11.96$ & $0.07-5.55$ & Seasonal & Present study \\
\hline${ }^{\mathrm{a}}$ Leaf & & & & & & \\
\hline
\end{tabular}




\section{Chlorophyll}

Chlorophyll (chl) concentrations in seagrasses fluctuate with variations in temperature and light regime (Wiginton \& McMillan 1979, Dennison \& Alberte 1982 1985, Macauley et al. 1988, Abal et al. 1994). Seagrasses typically respond to light reduction by increasing chl content and decreasing chl a:b ratios (Wiginton \& McMillan 1979, Dennison \& Alberte 1982, 1985 Abal et al. 1994, Lee \& Dunton 1996). However, we observed high chl concentrations and low chl $a: b$ ratios during the period of high underwater irradiance. These measurements are not in agreement with seagrass photoadaptation in response to underwater light stress, suggesting plants in this study area are not light limited.

Instead, the seasonal changes in total chl content and chl $a: b$ ratios noted in this study are similar to those noted by Macauley et al. (1988), who noted that Thalassia testudinum blade chl concentrations were highest and chl $a$ : $b$ ratios lowest during summer and early fall. These results provide evidence that variations in chl were related to water temperature and not to photoadaptative responses to changes in underwater irradiance. Chl is probably synthesized during high production periods (e.g. summer) to enhance light harvesting.

Leaf productivity and rhizome non-structural carbohydrate carbon content were closely correlated with chl content. The maximum chl concentration during June and July coincided with peaks of leaf productivity and rhizome carbohydrate carbon content. Photosynthesis was directly proportional to chl content in Posidonia oceanica (Drew 1978) and the highest $P_{\max }$ corresponded with a peak in total leaf chl in Halodule wrightii (Dunton \& Tomasko 1994). It is likely that increases in leaf productivity and rhizome carbohydrate carbon content are a consequence, at least in part, of increased photosynthesis in response to higher blade chl content.

\section{Non-structural carbohydrate carbon dynamics}

Measurement of the distinct seasonal changes in non-structural carbohydrate carbon content, as reported in this study, provides valuable information for modeling the whole plant carbon balance in Thalassia testudinum. Many researchers have calculated whole plant carbon balance based on estimates from laboratory measured photosynthesis vs irradiance ( $P$ vs $I$ ) curves and the respiration rates of different plant parts to understand seagrass growth and survival under different environmental conditions (Zimmermann et al. 1989, 1991, Fourqurean \& Zieman 1991). However, laboratory measurements of seagrass photosynthesis with leaf segments cannot always be extrapolated into the field (Dunton \& Tomasko 1994). In experiments with Zostera marina, Zimmermann et al. (1989) noted that respiration rates calculated from the incubation of root and rhizome tissues in the laboratory vary as a function of oxygen concentration in the incubation medium. Consequently, total plant respiration can be overestimated since rhizome and root tissues are usually located in anoxic sediments, not in a well ventilated water column

Seagrass rhizome tissues usually act as photosynthate storage tissue (Dawes \& Lawrence 1979, Durako \& Moffler 1985, Pirc 1985, 1989). Stored carbon can be used to meet respiratory demands and can contribute to plant growth when carbon demands exceed photosynthesis. Photosymthetic carbon accumulates as nonstructural carbohydrate in the rhizome tissues when photosynthesis exceeds the carbon demands from respiration and growth. Therefore, the increase in rhizome carbohydrate carbon content indicates a positive whole plant carbon balance against respiration and growth, while a decreased rhizome carbohydrate carbon indicates a negative carbon balance. In this study, rhizome carbohydrate carbon content increased dramatically during June and July, indicating periods of positive carbon balance. This rapid increase in rhizome carbohydrate carbon content coincided with high water temperatures and underwater irradiance, as well as high chl concentrations, low chl $a: b$ ratios and high leaf biomass. Since the plants experienced optimal environmental and biological conditions for high photosynthetic production, there was a net storage of non-structural carbohydrate carbon in the rhizome tissues. During winter and spring, the plants showed a negative whole plant carbon balance as rhizome carbohydrate carbon content decreased rapidly. The rapid decrease of carbohydrate carbon contents during spring was probably due to spring leaf growth (Dawes \& Lawrence 1979, Durako \& Moffler 1985, Pirc 1985, 1989). Tissues not used for storage of carbon, particularly leaf and root material, did not show strong seasonal trends in carbohydrate carbon content.

Acknowledgements. We thank J. Kaldy and S. Herzka for many hours of field assistance, and S. Schonberg and K. Jackson for computational and laboratory support. We also thank A. A.mos for the water temperature data. In addition to anonymous reviewers, S. Herzka, J. Kaldy and K. Machalek provided extremely helpful comments on earlier versions of this manuscript. This work was supported by the Texas Higher Education Coordınating Board Advanced Technology Program (Grant No. 3658-419 and 3658-426), Grant Nos. X996025-01-1 (EPA, Region 6) and funding from a Coastal Submerged Aquatic Vegetation Initiative, U.S. Environmental Protection Agency, Gulf Breeze, FL; Cooperative Agreement No. CR 820443-01-0. This is Contribution No. 974 of the University of Texas at Austin, Marine Science Institute. 


\section{LITERATURE CITED}

Abal EG, Loneragan N, Bowen P, Perry CJ, Udy JW, Dennison WC (1994) Physiological and morphological responses of the seagrass Zostera capricorni Aschers. to light intensity. J Exp Mar Biol Ecol 178:113-129

Buesa RJ (1974) Population and biological data on turtle grass (Thalassia testudinum König, 1805) on the Northwestern Cuban shelf. Aquaculture 4:207-226

Bulthuis DA (1987) Effects of temperature on photosynthesis and growth of seagrasses. Aquat Bot 27:27-40

Caffrey JM, Kemp WM (1991) Seasonal and spatial patterns of oxygen production, respiration and root-rhizome release in Potamogeton perfoliatus L. and Zostera marina L. Aquat Bot 40:109-128

Chin-Leo G, Benner R (1991) Dynamics of bacterioplankton abundance and production in seagrass communities of a hypersaline lagoon. Mar Ecol Prog Ser 73:219-230

Czerny AB, Dunton KH (1995) The effects of in situ light reduction on the growth of two species of subtropical seagrasses, Thalassia testudinum and Halodule wrightii. Estuaries 18:418-427

Dawes CJ, Guiry MD (1992) Proximate constituents in the seagrasses Zostera marina and $Z$. noltii in Ireland: seasonal changes and the effect of blade removal. PSZN I: Mar Ecol 13:307-315

Dawes CJ, Lawrence JM (1979) Effects of blade removal on the proximate composition of the rhizome of the seagrass Thalassia testudinum Banks ex König. Aquat Bot 7:255-266

Dawes CJ, Lawrence JM (1980) Seasonal changes in the proximate constituents of the seagrasses Thalassia tes. tudinum, Halodule wrightii, and Syringodium filiforme. Aquat Bot 8:371-380

Dawes CJ, Tomasko DA (1988) Depth distribution of Thalassia testudinum in two meadows on the west coast of Florida; a difference in effect of light availability. PSZN I: Mar Ecol 9:123-130

Dennison WC, Alberte RS (1982) Photosynthetic responses of Zostera marina L. (eelgrass) to in situ manipulations of light intensity. Oecologia 55:137-144

Dennison WC, Alberte RS (1985) Role of daily light period in the depth distribution of Zostera marina (eelgrass). Mar Ecol Prog Ser 25:51-61

Drew EA (1978) Factors affecting photosynthesis and its seasonal variation in the seagrasses Cymodocea nodosa (Ueria) Aschers. and Posidonia oceanica (L.) Delile in the Mediterranean. J Exp Mar Biol Ecol 31:173-194

Dunton KH (1990) Production ecology of Ruppia maritima L. s.1. and Halodule wrightii Aschers. in two subtropical estuaries. J Exp Mar Biol Ecol 143:147-164

Dunton KH (1994) Seasonal growth and biomass of the subtropical seagrass Halodule wrightii in relation to continuous measurements of underwater irradiance. Mar Biol 120:479-489

Dunton KH (1996) Photosynthetic production and biomass of the subtropical seagrass Halodule wrightii along an estuarine gradient. Estuaries 19:436-447

Dunton KH, Tomasko DA (1994) In situ photosynthesis in the seagrass Halodule wrightii in a hypersaline subtropical lagoon. Mar Ecol Prog Ser 107:281-293

Durako MJ, Moffler MD (1985) Spatial influences on temporal variations in leaf growth and chemical composition of Thalassia testudinum Banks ex König in Tampa Bay. Florida. Gulf Res Rep 8:43-49

Fourqurean JW, Zieman JC (1991) Photosynthesis, respiration and whole plant carbon budget of the seagrass Thalassia testudinum. Mar Ecol Prog Ser 69:161-170
Gallegos ME, Merino M. Marbá N, Duarte CM (1993) Biomass and dynamics of Thalassia testudinum in the Mexi. can Caribbean: elucidating rhizome growth. Mar Ecol Prog Ser 95:185-192

Heck KL Jr, Westone GS (1977) Habitat complexity and invertebrate species richness and abundance in tropical seagrass meadows. J Biogeogr 4:135-142

Huh SH, Kitting CL (1985) Trophic relationships among concentrated populations of small fishes in seagrass meadows. J Exp Mar Biol Ecol 92:29-43

Jeffrey SW. Humphrey GF (1975) New spectrophotometric equations for determining chlorophylls $a, b, c 1$ and $c 2$ in higher plants, algae and natural phytoplankton. Biochem Physiol Pflanz 167:191-194

Kentula ME, McIntire CD (1986) The autecology and production dynamics of eelgrass (Zostera marina L.) in Netarts Bay, Oregon. Estuaries 9:188-199

Kenworthy WJ, Thayer GW (1984) Production and decomposition of the roots and rhizomes of seagrasses, Zostera marina and Thalassia testudinum, in temperate and subtropical marine ecosystems. Bull Mar Sci 35:364-379

Koepfler ET, Benner R, Montagna PA (1993) Variability of dissolved organic carbon in sediments of a seagrass bed and an unvegetated area within an estuary in southern Texas Estuaries 16:391-404

Kraemer GP, Alberte RS (1993) Age-related patterns of metabolism and biomass in subterranean tissues of Zostera marina (eelgrass). Mar Ecol Prog Ser 95:193-203

Lee KS, Dunton KH (1996) Effects of in situ light reduction on the maintenance, growth and partitioning of carbon resources in Thalassia testudinum. J Exp Mar Biol Ecol (in press)

Macauley JM, Clark JR, Price WA (1988) Seasonal changes in the standing crop and chlorophyll content of Thalassia testudinum Banks ex König and its epiphytes in the northern Gulf of Mexico. Aquat Bot 31:277-287

Mann KH (1988) Production and use of detritus in various freshwater, estuarine, and coastal marine ecosystems Limnol Oceanogr 33:910-930

McRoy CP, McMillan C (1977) Production ecology and physiology of seagrasses. In: McRoy CP, Helfferich C (eds) Seagrass ecosystems: a scientific perspective. Dekker, New York, p 53-81

Ogden JC (1980) Faunal relationships in Caribbean seagrass beds. In: Phillips RC, McRoy CP (eds) Handbook of seagrass biology: an ecosystem perspective. Garland STPM Press, New York, p 173-198

Opsahl S, Benner R (1993) Decomposition of senescent blades of the seagrass Halodule wrightii in a subtropical lagoon. Mar Ecol Prog Ser 94:191-205

Orth RJ, Heck KL Jr, Montfrans J van (1984) Faunal communities in seagrass beds: a review of the influence of plant structure and prey characteristics on predator-prey relationships. Estuaries 7:339-350

Ott JA (1979) Persistence of a seasonal growth rhythm in Posidonia oceanica (L.) Delile under constant conditions of temperature and illumination. Mar Biol Lett 1: 99-104

Pakulski JD, Benner $R$ (1992) An improved method for the hydrolysis and MBTH analysis of dissolved and particulate carbohydrates in seawater. Mar Chem 40 $143-160$

Parsons TR, Maita Y, Lalli CM (1984) A manual of chemical and biological methods for seawater analysis. Pergamon Press, New York

Peduzzi P, Herndl GJ (1991) Decomposition and significance of seagrass leaf litter (Cymodocea nodosa) for the micro- 
bial food web in coastal waters (Gulf of Trieste, Northern Adriatic Sea). Mar Ecol Prog Ser 71:163-174

Pergent G, Pergent-Martini C (1991) Leaf renewal cycle and primary production of Posidonia oceanicd in the bay of Lacco Ameno (Ischia, Italy) using lepidochronological analysis. Aquat Bot 42:49-66

Phillips RC, McMillan C, Bridges KW (1983) Phenology of eelgrass, Zostera marina L., along latitudinal gradients in North America. Aquat Bot 15:145-156

Pirc H (1985) Growth dynamics in Posidonia oceanica (L.) Delile. I. Seasonal changes of soluble carbohydrates, starch, free amino acids, nitrogen and organic anions in different parts of the plant. PSZN I: Mar Ecol 6: $141-165$

Pirc H (1989) Seasonal changes in soluble carbohydrates, starch, and energy content in Mediterranean seagrasses. PSZN I: Mar Ecol 10:97-105

Powell GVN, Kenworthy WJ, Fourqurean JW (1989) Experimental evidence for nutrient limitation of seagrass growth in a tropical estuary with restricted circulation. Bull Mar Sci 44:324-340

Ralph PJ, Burchett MD, Pulkownik A (1992) Distribution of extractable carbohydrate reserves within the rhizome of the seagrass Posidonia australis Hook. f. Aquat Bot 42 $385-392$

Roman CT, Able KW (1988) Production ecology of eelgrass (Zostera marina L.) in a Cape Cod salt marsh-estuarine system, Massachusetts. Aquat Bot 32:353-363

Sand-Jensen K, Borum J (1983) Regulation of growth of eelgrass (Zostera marina L.) in Danish coastal waters. Mar Technol Soc J 17:15-21

SAS Institute (1989) SAS/STAT guide for personal computers, version 6, 4th edn. SAS Institute, Inc, Cary, NC

Setchell WA (1929) Morphological and phenological notes on Zostera marina L. Univ Calif Publ Bot 14:389-452

Smith RD, Dennison WC, Alberte RS (1984) Role of seagrass photosynthesis in root aerobic processes. Plant Physiol 74 $1055-1058$

Summerson HC, Peterson CH (1984) Role of predation in organizing benthic communities of a temperate-zone seagrass bed. Mar Ecol Prog Ser 15:63-77

This article was submitted to the editor
Thom RM (1990) Spatial and temporal patterns in plant standing stock and primary production in a temperate seagrass system. Botanica Mar 33:497-510

Tomasko DA, Lapointe BE (1991) Productivity and biomass of Thalassia testudinum as related to water column nutnent availabllity and epiphyte levels: field observations and expermental studies. Mar Ecol Prog Ser 75:9-17

Tussenbroek BI van (1995) Thalassia testudinum leaf dynamics in a Mexican Caribbean coral reef lagoon. Mar Biol $122: 33-40$

Tutin TG (1942) Zostera. J Ecol 30:217-266

Vermaat JE, Hootsmans MJM, Nienhuis PH (1987) Seasonal dynamics and leaf growth of Zostera noltii Hornem., a perennial intertidal seagrass. Aquat Bot 28:287-299

Wetzel RL, Penhale PA (1983) Production ecology of seagrass communities in the lower Chesapeake Bay. Mar Technol Soc J 17:22-31

Wiginton JR, McMillan C (1979) Chlorophyll composition under controlled light conditions as related to the distribution of seagrasses in Texas and U.S. Virgin Islands. Aquat Bot 6:171-184

Williams SL (1988) Thalassia testudinum productivity and grazing by green turtles in a highly disturbed seagrass bed. Mar Biol 98:447-455

Zieman JC (1974) Methods for the study of the growth and production of turtle grass, Thalassia testudinum König. Aquaculture 4:139-143

Zieman JC (1975) Quantitative and dynamic aspects of the ecology of turtle grass, Thalassia testudinum. In: Cronin LE (ed) Estuarine research, Vol 1, Chemistry, biology and estuarne system. Academic Press, New York, p 541-562

Zieman JC, Fourqurean JW, Iverson RL (1989) Distribution, abundance and productivity of seagrasses and macroalgae in Florida Bay. Bull Mar Sci 44:292-311

Zimmerman RC, Reguzzoni JL, Wyllie-Echeverria S, Josselyn M, Alberte RS (1991) Assessment of environmental suitability for growth of Zostera marina L. (eelgrass) in San Francisco Bay. Aquat Bot 39:353-366

Zimmerman RC, Smith RD. Alberte RS (1989) Thermal acclimation and whole-plant carbon balance in Zostera manna L. (eelgrass). J Exp Mar Biol Ecol 130:93-109

Manuscript first received: February 13, 1996 Revised version accepted: September 4, 1996 